\title{
Experimental Study on the Quality of Dutch Cucumber in Storage
}

\author{
Jingying $\operatorname{Tan}^{1}$, Dan Jin ${ }^{2}$, and Qing Wang ${ }^{1}$ \\ ${ }^{1}$ School of Mechanical Engineering, Hunan Institute of Science and Technology, \\ Yueyang, Hunan Province, China 41400 \\ ${ }^{2}$ School of Mechanical Engineering, Shenyang University of Chemical Technology, \\ Shenyang, Liaoning Province, China, 110142 \\ \{jingyingtan, jindan76, wqwyy\}@163.com
}

\begin{abstract}
The quality of Dutch cucumbers in storage was investigated by four kinds of storage technique, especially such as weight loss, soluble solid content, firmness and their appearance. The results indicates that the quality of the Dutch cucumbers stored after pre-cooling is very near that of those stored after preheating, while they are higher than that of those primarily stored. And the quality of those stored in room-temperature. The quality of Dutch cucumbers with preservative film excels that of those without it by the same technique. Therefore it is a good way to precool or preheat the cucumbers and latter to pack them with preservative film before their storage to sustain the fresh quality of Dutch cucumbers.
\end{abstract}

Keywords: storage technique cucumber quality weight loss soluble solid content firmness

\section{Introduction}

Cucumber (Cucumis sativus L) is a chilling sensitive commodity. It is very welcomed for its delicious brilliance and high nutrition. But it goes bad in a short time after harvest. Some key qualities of cucumbers such as weight, soluble solid content, firmness and their appearance decreases soon. It is very concerned to keep cucumbers fresh after harvest all the along. Jennifer R. DeEll , etc[1] studied water temperature for hydrocooling field cucumbers in relation to chilling injury during storage. Abdul Hakim, Albert C. Purvis, and Ben G. Mullinix [2]pointed out differences in chilling sensitivity of cucumber varieties depends on storage temperature and the physiological dysfunction evaluated. Rob E. Schouten, L.M.M. Tijskens, Olaf van Kooten[3]Predicted keeping quality of cucumber fruit based on a physiological mechanism. Pan Yonggui[4,5] etc studied effects of Intermittent Warming on cucumber storage. Hou Jian-she etc[6] investigated effects of prestorage treatment on chilling endurance and free radical biology. The objective of this study was to find a new economic technique to sustain the freshest possible quality of cucumbers in longest possible shelf life. Weight loss, soluble solid content, firmness and appearance of cucumbers were used to assess the effects of storage. 


\section{Materials and Methods}

\subsection{Materials}

Freshly harvested field cucumbers were obtained from Tianjin farming demonstration center during May12, 2005. All of them were carried to the preservative cold-storage at once after harvest. Marketable cucumbers of similar size, color and color but without mechanical damage and insect pest were selected for the experiments.

\subsection{Quality Measurement, Instruments and Storage Techniques}

\subsubsection{Quality Measurement and Instruments}

1) Loss weight in storage

It was measured by JA5003H, 1/1000 scale made in Shanghai precise instrument plant, China.

2) soluble solid content in Dutch cucumber

It was measured with WYT saccharimeter made in Chengdu optical plant, China.

3) Dutch cucumber firmness

It was measured by GY-1 hardmeter made in Mudanjiang mechine research institute, China.

4) Dutch cucumber appearance

Dutch cucumber appearance was assessed by eye-measurement.

\subsubsection{Storage Techniques}

Experimental cucumbers were randomly sorted to 4 groups, as follows:

Group a

Cucumbers were directly stored in $25^{\circ} \mathrm{C}, 70 \% \mathrm{RH}$.

Group b

Cucumbers were directly stored in $4^{\circ} \mathrm{C}, 95 \% \mathrm{RH}$.

Group c

Cucumbers were stored in $4^{\circ} \mathrm{C}, 95 \% \mathrm{RH}$ after being precooled to $4^{\circ} \mathrm{C}$.

Group d

Cucumbers were stored in $4{ }^{\circ} \mathrm{C}, 95 \% \mathrm{RH}$ after being preheated to $4^{\circ} \mathrm{C}$ and sustaining for 24 hours.

Each group is classified to two kinds as follows:

Group *1 means cucumbers stored without preservative film and Group *2 means cucumbers stored with preservative film, where symbol * stands for a, b, c, or d.

\section{Results and Discussions}

\subsection{Effects of Different Techniques on Weight Loss of Dutch Cucumbers}

Weight loss of cucumbers is affected by many factors. On the one hand, it is related to physical construction of Dutch cucumbers themselves, such as specific surface areas, surface histology, cell retention ability and cell gap length. Specific surface areas indicate areas per gramme cucumber. Surface histology means the natural duct and 
cuticle layer. The natural duct is made up of gas porosity and cortical pore which is open in the surface of cucumbers. Water diffusion in cucumber was affected by cuticle layer. Cell retention ability is expressed by the content of soluble substance and hydrophilia colloid in the cell. Cell gap affects the drag force of water diffusion. On the other hand, weight loss was also affected by external factors, such as temperature, relative humidity, air speed, light and air pressure. Weight loss per time and per surface areas is calculated as equation (1).

$$
d m / d t=-k
$$

Given a constant temperature, equation (2) is obtained

$$
m=m_{0}-k t
$$

Where $\mathrm{m}$ is the mass at time $\mathrm{t}, \mathrm{m}_{0}$ is the initial value of $\mathrm{m}$.

Therefore, weight loss ratio $m$ is obtained as follows:

$$
m=\frac{m_{0}-m}{m_{0}}=p t
$$

where $\mathrm{p}$ is constant.

Relations between weight loss ratio of cucumber and storage time is described in Fig. 1. After 16 days of cucumbers storage, it is concluded that the four close values among 1.4-1.9 of weight loss ratio of cucumber with preservative film in the 4 different groups show powerful ability of preservative film to control weight loss ratio. Preservative film not only provides a high humidity condition to prevent the water evaporation from the surface of cucumbers but also decreases the metabolism of them. Without Preservative film, weight loss ratio of group a was the biggest, amounting to $11.81 \%$, where cucumbers looked wilt. The one of $\mathrm{b}$ group took second place, the value of which is $7.11 \%$. The one of $\mathrm{c}$ group and the one of $\mathrm{d}$ group are very nice, respectively $4.71 \%$ and $4.02 \%$, and the cucumbers in these two groups looked fresh.

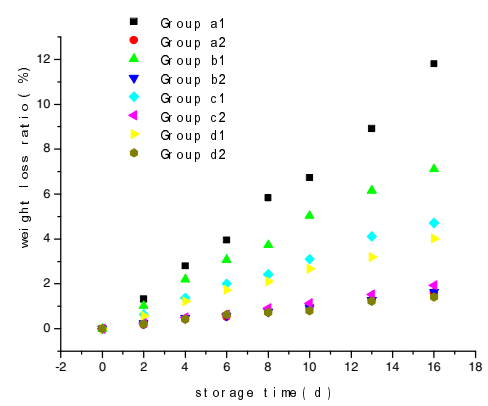

Fig. 1. Relations between weight loss ratio and storage time 
According to Fig. 1, the fitting value of $\mathrm{p}$ in equation (3) was obtained as Table1.

Table 1. The fitting values of $\mathrm{p}$

\begin{tabular}{ccccccccc}
\hline Groups & a1 & a2 & b1 & b2 & c1 & c2 & d1 & d2 \\
\hline $\mathrm{p}$ & 0.70764 & 0.09674 & 0.47007 & 0.09957 & 0.30706 & 0.09957 & 0.257 & 0.0902 \\
s.e & \pm 0.0120 & \pm 0.00179 & \pm 0.01083 & \pm 0.00212 & \pm 0.00524 & \pm 0.00194 & \pm 0.00557 & \pm 0.00261 \\
\hline $\mathrm{R}^{2}$ & 0.99295 & 0.99174 & 0.984 & 0.98767 & 0.99164 & 0.99315 & 0.98561 & 0.97551 \\
\hline
\end{tabular}

\subsection{Effects of Different Techniques on Soluble Solid Content of Dutch Cucumbers}

There is different for soluble solid content in different position, for example, the higher soluble solid content for cucumber head, the lower for behind-of-center and almost zero soluble solid content for cucumber tail and it is difficult to measure the soluble solid content. The soluble solid content value is given by the mean value of soluble solid content in 6-7 points for different position. Soluble solid content of cucumber is $4.5-4.8 \%$ in experiment beginning.

It is shown from Fig. 2 and Fig. 3 that soluble solid content of cucumber decreases significantly with the storage time increasing for all experiment data, i.e., the property of storage cucumber is worse obvious than that of experiment beginning. Comparing the different experiment groups, it can be observed that the soluble solid content of

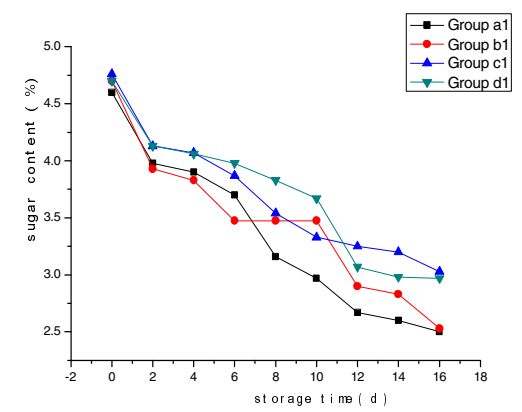

Fig. 2. Soluble solid content of cucumber with time except the preservative film

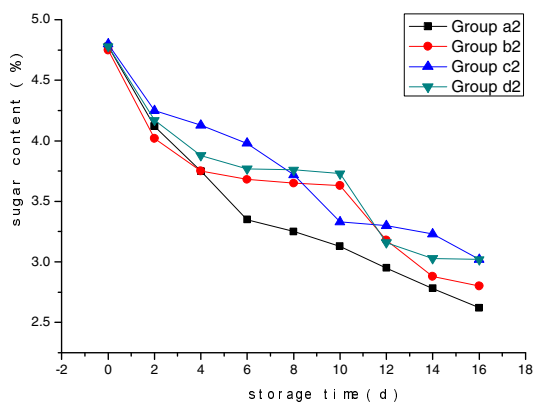

Fig. 3. Soluble solid content of cucumber with time by the preservative film 
cucumber by precooling and preheating treating groups is higher than that of the direct cool storage and room-temperature group. The property of the first two groups is better than that of other two groups. On the whole, the soluble solid content of cucumber in the preservative film is higher than that of the corresponding contrast group. It is shown that the better storage result is obtained by using the preservative bag.

\subsection{Effects of Different Techniques on Firmness of Dutch Cucumbers}

Cucumber firmness is different for different position. Generally, it is soft for cucumber head and hard for cucumber tail. So 7 8 points in different position are chosen for measuring and the mean value is considered as the cucumber firmness. The changes of cucumber firmness with time for different treating groups are shown in Fig. 4.

As observed in Fig. 5, the cucumber firmness for experiment groups decreases with time, i.e., the property of storage cucumber is worse than that of experiment beginning. But on the whole, the storage results for three cold-storage groups are better than that of room temperature groups. The effect of preservative bag package for cucumber firmness is not significant and the former result is a little better than that of the latter. The difference is between 0.6 and 1.1 .

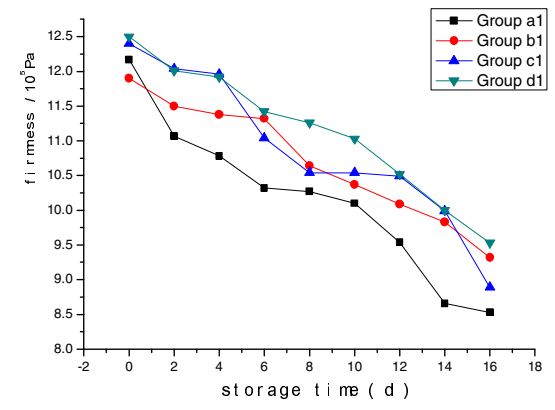

Fig. 4. Storage cucumber firmness with time except the package film

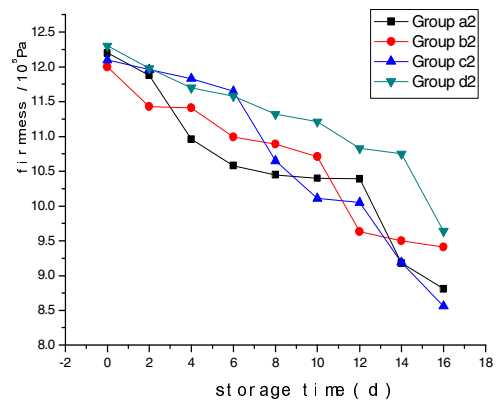

Fig. 5. Storage cucumber firmness with time by the package film 


\subsection{Effects of Different Techniques on Appearance of Dutch Cucumbers}

The observed results for appearance of cucumber are shown in Table 2. The appearance for room temperature storage except the preservative film decreases quickly, the appearance with the preservative film by precooling is equivalent to that of preheating treatment. The appearance by precooling and preheating is best for all treating condition and that of direct cool storage is in the middle.

Table 2. Appearance contrast for different experiment group cucumbers

\begin{tabular}{|c|c|c|c|c|}
\hline $\begin{array}{l}\text { Time(d) } \\
0\end{array}$ & $\begin{array}{l}\text { Group a1 } \\
\text { Fresh cucumber }\end{array}$ & $\begin{array}{l}\text { Group a2 } \\
\text { Fresh cucumber }\end{array}$ & $\begin{array}{l}\text { Group b1 } \\
\text { Fresh } \\
\text { cucumber }\end{array}$ & $\begin{array}{l}\text { Group b2 } \\
\text { Fresh cucumber }\end{array}$ \\
\hline 2 & $\begin{array}{l}\text { Froth appearance } \\
\text { in surface }\end{array}$ & $\begin{array}{l}\text { The same with } \\
\text { that of the } \\
\text { nearest above }\end{array}$ & $\begin{array}{l}\text { The same } \\
\text { with that of } \\
\text { the nearest } \\
\text { above }\end{array}$ & $\begin{array}{l}\text { The same with } \\
\text { that of the } \\
\text { nearest above }\end{array}$ \\
\hline 4 & $\begin{array}{l}\text { Froth and macula, } \\
\text { appearance in } \\
\text { surface, coarseness }\end{array}$ & $\begin{array}{l}\text { The same with } \\
\text { that of the } \\
\text { nearest above }\end{array}$ & $\begin{array}{l}\text { The same } \\
\text { with that of } \\
\text { the nearest } \\
\text { above }\end{array}$ & $\begin{array}{l}\text { The same with } \\
\text { that of the } \\
\text { nearest above }\end{array}$ \\
\hline 6 & $\begin{array}{l}\text { Froth appearance } \\
\text { in } 80 \% \text { surface }\end{array}$ & $\begin{array}{l}\text { Little froth } \\
\text { appearance in } \\
\text { surface }\end{array}$ & $\begin{array}{l}\text { The same } \\
\text { with that of } \\
\text { the nearest } \\
\text { above }\end{array}$ & $\begin{array}{l}\text { The same with } \\
\text { that of the } \\
\text { nearest above }\end{array}$ \\
\hline 8 & $\begin{array}{l}\text { Froth and macula, } \\
\text { white in cucumber }\end{array}$ & $\begin{array}{l}\text { The same with } \\
\text { that of the } \\
\text { nearest above }\end{array}$ & $\begin{array}{l}\text { The same } \\
\text { with that of } \\
\text { the nearest } \\
\text { above }\end{array}$ & $\begin{array}{l}\text { The same with } \\
\text { that of the } \\
\text { nearest above }\end{array}$ \\
\hline 10 & $\begin{array}{l}\text { serious froth } \\
\text { appearance in } 90 \% \\
\text { surface, white } \\
\text { in cucumber, } \\
\text { no sweet }\end{array}$ & $\begin{array}{l}\text { Fresh green in } \\
\text { cucumber, sweet }\end{array}$ & $\begin{array}{l}\text { The same } \\
\text { with that of } \\
\text { the nearest } \\
\text { above }\end{array}$ & $\begin{array}{l}\text { Little chilling } \\
\text { injury } \\
\text { appearance }\end{array}$ \\
\hline 12 & $\begin{array}{l}\text { serious froth } \\
\text { appearance in all } \\
\text { surface, complete } \\
\text { white in cucumber, }\end{array}$ & $\begin{array}{l}\text { Froth } \\
\text { appearance in } \\
\text { almost surface, } \\
\text { green in } \\
\text { cucumber }\end{array}$ & $\begin{array}{l}\text { Half chilling } \\
\text { injury, more } \\
\text { serious }\end{array}$ & $\begin{array}{l}\text { chilling injury } \\
\text { appearance, } \\
\text { little thickness } \\
\text { in surface }\end{array}$ \\
\hline 14 & $\begin{array}{l}\text { Little yellow } \\
\text { appearance } \\
\text { in froth position, } \\
\text { soft }\end{array}$ & $\begin{array}{l}\text { The same with } \\
\text { that of the } \\
\text { nearest above }\end{array}$ & $\begin{array}{l}\text { Serious } \\
\text { chilling } \\
\text { injury, } \\
\text { surface } \\
\text { thicker }\end{array}$ & $\begin{array}{l}\text { chilling injury } \\
\text { in } 40 \% \text { surface, } \\
\text { more serious } \\
\text { surface } \\
\text { thickness }\end{array}$ \\
\hline 16 & $\begin{array}{l}\text { Yellow appearance } \\
\text { in froth position, } \\
\text { very soft }\end{array}$ & $\begin{array}{l}\text { The same with } \\
\text { that of the } \\
\text { nearest above }\end{array}$ & $\begin{array}{l}\text { chilling } \\
\text { injury in } \\
75 \% \text { surface, } \\
\text { surface } \\
\text { thickness }\end{array}$ & $\begin{array}{l}\text { more serious } \\
\text { chilling injury }\end{array}$ \\
\hline
\end{tabular}


Table 2 (Continued)

\begin{tabular}{|c|c|c|c|c|}
\hline $\operatorname{Time}(d)$ & Group c1 & Groupc2 & Group d1 & Group d2 \\
\hline $\mathbf{0}$ & Fresh cucumber & Fresh cucumber & $\begin{array}{l}\text { Fresh } \\
\text { cucumber }\end{array}$ & Fresh cucumber \\
\hline 2 & $\begin{array}{l}\text { The same with that } \\
\text { of the nearest } \\
\text { above }\end{array}$ & $\begin{array}{l}\text { The same with } \\
\text { that of the } \\
\text { nearest above }\end{array}$ & $\begin{array}{l}\text { The same } \\
\text { with that of } \\
\text { the nearest } \\
\text { above }\end{array}$ & $\begin{array}{l}\text { The same with } \\
\text { that of the } \\
\text { nearest above }\end{array}$ \\
\hline 4 & $\begin{array}{l}\text { The same with that } \\
\text { of the nearest } \\
\text { above }\end{array}$ & $\begin{array}{l}\text { The same with } \\
\text { that of the } \\
\text { nearest above }\end{array}$ & $\begin{array}{l}\text { The same } \\
\text { with that of } \\
\text { the nearest } \\
\text { above }\end{array}$ & $\begin{array}{l}\text { chilling injury } \\
\text { appearance }\end{array}$ \\
\hline 6 & $\begin{array}{l}\text { The same with that } \\
\text { of the nearest } \\
\text { above }\end{array}$ & $\begin{array}{l}\text { The same with } \\
\text { that of the } \\
\text { nearest above }\end{array}$ & $\begin{array}{l}\text { The same } \\
\text { with that of } \\
\text { the nearest } \\
\text { above }\end{array}$ & $\begin{array}{l}\text { The same with } \\
\text { that of the } \\
\text { nearest above }\end{array}$ \\
\hline 8 & $\begin{array}{l}\text { The same with that } \\
\text { of the nearest } \\
\text { above }\end{array}$ & $\begin{array}{l}\text { The same with } \\
\text { that of the } \\
\text { nearest above }\end{array}$ & $\begin{array}{l}\text { The same } \\
\text { with that of } \\
\text { the nearest } \\
\text { above }\end{array}$ & $\begin{array}{l}\text { The same with } \\
\text { that of the } \\
\text { nearest above }\end{array}$ \\
\hline 10 & $\begin{array}{l}\text { The same with that } \\
\text { of the nearest } \\
\text { above }\end{array}$ & $\begin{array}{l}\text { The same with } \\
\text { that of the } \\
\text { nearest above }\end{array}$ & $\begin{array}{l}\text { chilling } \\
\text { injury } \\
\text { appearance }\end{array}$ & $\begin{array}{l}\text { The same with } \\
\text { that of the } \\
\text { nearest above }\end{array}$ \\
\hline 12 & $\begin{array}{l}\text { chilling injury } \\
\text { appearance, } \\
\text { surface thickness }\end{array}$ & $\begin{array}{l}\text { White thickness } \\
\text { liquid } \\
\text { appearance }\end{array}$ & $\begin{array}{l}\text { chilling } \\
\text { injury } \\
\text { appearance, } \\
\text { surface } \\
\text { thickness }\end{array}$ & $\begin{array}{l}\text { White thickness } \\
\text { liquid } \\
\text { appearance }\end{array}$ \\
\hline 14 & $\begin{array}{l}\text { chilling injury in } \\
50 \% \text { surface, } \\
\text { surface thickness }\end{array}$ & $\begin{array}{l}\text { Little chilling } \\
\text { injury }\end{array}$ & $\begin{array}{l}50 \% \text { little } \\
\text { chilling } \\
\text { injury, } \\
\text { surface } \\
\text { thickness }\end{array}$ & $\begin{array}{l}\text { Little chilling } \\
\text { injury }\end{array}$ \\
\hline 16 & $\begin{array}{l}\text { more serious } \\
\text { chilling injury }\end{array}$ & $\begin{array}{l}\text { The same with } \\
\text { that of the } \\
\text { nearest above }\end{array}$ & $\begin{array}{l}\text { The same } \\
\text { with that of } \\
\text { the nearest } \\
\text { above }\end{array}$ & $\begin{array}{l}\text { The same with } \\
\text { that of the } \\
\text { nearest above }\end{array}$ \\
\hline
\end{tabular}

Experiment finishing, the photos of cucumbers in all groups are shown in Fig. 6 9.

Group a:

They are shown in Fig. 6. Group a2 lies in nearest above /up and group a1 right /down.

There is an amount of froth in the cucumber surface of group a1 and the surface has become yellow too. There is only the froth in the surface of group a2. Comparing the section, it can be seen that the inside of group a1 has become white and group a2 green. 

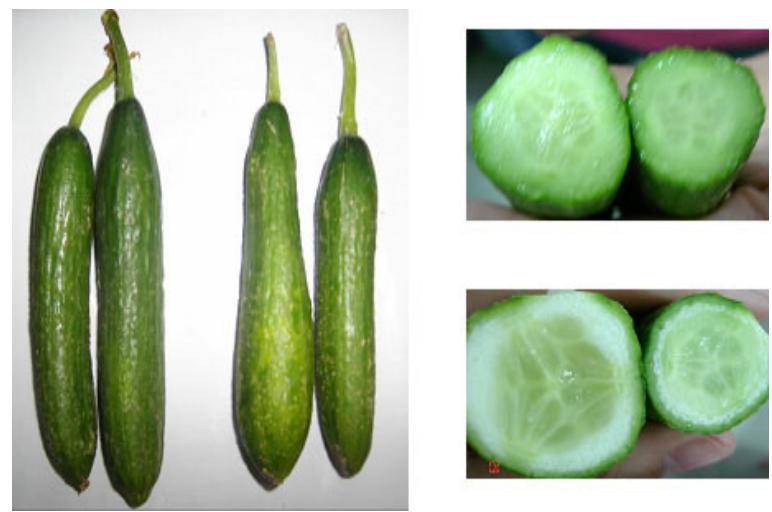

Fig. 6. Appearance and cross section in group a

Group b

They are shown in Fig. 7. Group b1 lies in right /up and group b 2 nearest above /down.
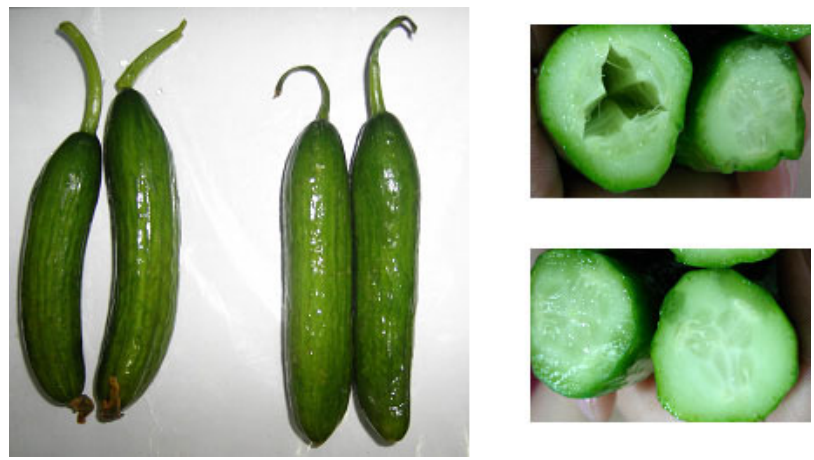

Fig. 7. Appearance and cross section in Group b

From the surface, the storage quality for cool storage group is better than that of the room temperature group but the chilling injury is obvious. The cucumber tail has withered and cucumber inside has be empty. It can be seen from the group 1 . So the cucumber quality of group 2 is better than that of group 1 .

Group c

They are shown in Fig. 8. Group c1 lies in right /up and Group c 2 / nearest above down.

The surface symptom for precooling groups and preheating groups is almost the same. There is the chilling injury (due to no aseptic treatment before storage). Comparing the second group and the first group, the storage quality for the second group is better than that of the first group. 

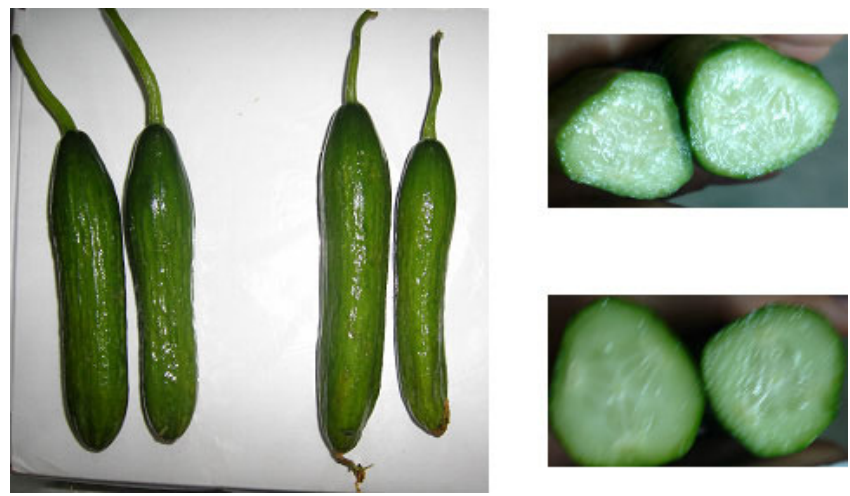

Fig. 8. Appearance and cross section in group c

Group d:

They are shown in Fig. 9. Group d1 lies in nearest above /up and Group d 2 right /down.
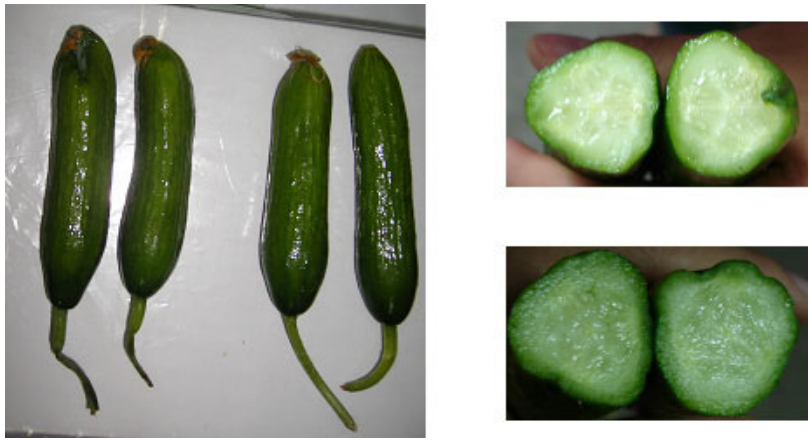

Fig. 9. Appearance and cross section in group d

From the surface, the storage quality for preheating group is better than that of the room temperature group. There is chilling injury appearance for the two preheating groups(due to no aseptic treatment before storage). Comparing the two groups, the chilling injury for group 1 is more obvious and the cucumber tail of group 1 has withered. But the cucumber tail of group 2 is good.

As a result, it is observed that different states are gained for different groups cucumbers by 16 days storage. So the property for different pretreatment methods and storage forms is directly shown from the phenomena.

\section{Conclusions}

From the experiment results, it is concluded that it is important for Dutch cucumbers storage to adopt low temperature and high humidity. The low temperature reduces the 
cucumber metabolism and the high humidity keeps the moisture content of cucumber so as to keep the cucumber refresh. It is an important means to maintain the fruit and vegetable quality by pretreatment. The suitable precooling and preheating treating can improve the storage quality of cucumber. The better quality can be gained by using the preservative film based on the pretreatment, especially its controlling the cucumber dehydration preferably and preventing soluble solid content from decreasing so as to keep the cucumber fresh and essential saccharinity. But preservative film has little effect on firmness of the cucumbers during storage.

\section{Acknowledgements}

The authors are grateful for A Project Supported by Scientific Research Fund of Hunan Provincial Education Department (10B043), A Project Supported by Scientific Research Fund of department of science and technology Hunan Province P. R. China (2008FJ3041) and A Project Supported by Scientific Research Fund of Hunan Institute of Science and Technology(2010Y38).

\section{References}

1. Jennifer, R.D., Vigneault, C., Lemerre, S.: Water temperature for hydrocooling field cucumbers in relation to chilling injury during storage. Postharvest Biology and Technology 18, 27-32 (2000)

2. Abdul, H., Albert, C.P., Mullinix, B.G.: Differences in chilling sensitivity of cucumber varieties depends on storage temperature and the physiological dysfunction evaluated. Postharvest Biology and Technology 17, 97-104 (1999)

3. Schouten, R.E., Tijskens, L.M.M., van Kooten, O.: Predicting keeping quality of cucumber fruit based on a physiological mechanism

4. Pan, Y.G., Li, Z.G.: Effect of Intermittent Warming on Membrance-Lipid Peroxidation System of Cucumber Fruit. Chinese Journal of Tropical Crops 24, 30-32 (2003)

5. Pan, Y.G., Li, Z.G.: Study on effects of Intermittent Warming on chilling harm. Journal of Southwest Agricultural University 2, 121-123 (2002)

6. Hou, J.S., Xi, Y.F., Li, Z.H.: Effects of prestorage treatment on chilling endurance and free radical biology. Food and Fermentation Industries 5, 138-142 (2004) 